Oct., Nov., Dec., 1951

\title{
Saskatchewan's Sweetest Scented Flower
}

\section{Archie Budd, Swift Current.}

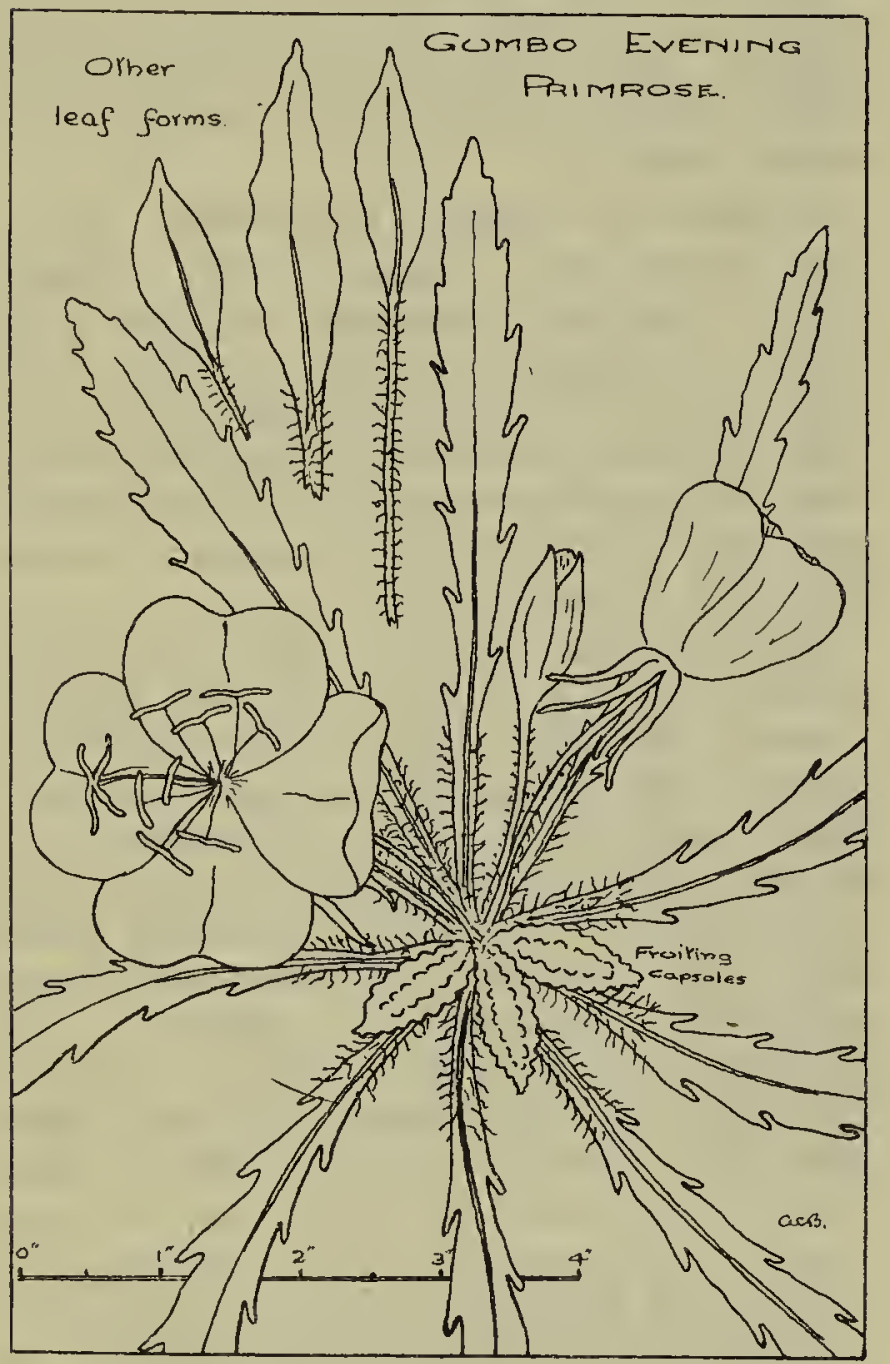

PERHAPS the sweetest smelling native Saskatchewan flower is the Gumbo Ev e n i n g-P r i m r o s e, Oenothera caespitosa, generally represented here by the variety montana. This is a low growing perennial of the Onagracese or Evening Primrose family and is nearly caespitose or stemless, the leaf and flower stalks arising almost directly from the crown of the long tap root. The leaves are generally long lanceolate with winged stalks, and $\mathrm{v}$ ary in length from an inch to eight inches, and in form from entire mergined to toothed, and generally have a pale mid-rib.

The flowers are very large and showy, from one and a half to three inches across, with four sepals, soon turning downwards, and four large white petals which open during the night but turn pink and wither in the late morning. Looking into the sweet scented open flower we find eight yellow stamens with their anthers horizontally on top of the filaments, and a yellow pistil consisting of a thin style with a fourlobed cross-like stigma on the summit. The fruit are rather hard, ovoid capsules from a half to one and a quarter inches long, borne closely on the root crown and ribbed with knobby ridges.

The Gumbo Evening-primrose is found on hillsides where the soil or subsoil is clay, and also on clay flats and coulee bottoms, and generally flowers during late May, June and early July. The typical form is practically hairless but most of our western plants are the variety montana which has a rough, white hairiness on the leaf stalks, flowerstems and base of the the plant.

In the native state the flowering period is fairly short but it has been found that under transplanting and cultivation it can be extended almost until freeze-up. It is a lovely plant for the garden with its showy, snow white petals and its golden yellow stamens and pistil and also the sweet, delicate scent in the early mornings.

\section{Golden Chokecherries}

W ${ }^{\mathrm{E}}$ were surprised and pleased to receive from Mr. Cliff Shaw, during the first week in September, a package of golden-yellow chokecherries found in the vicinity of Yorkton.

Mr. Shaw admits that he was very skeptical about the reports of these berries until he and another naturalist friend went out and saw them. There were five trees, ten to fifteen feet high, all heavily loaded and growing among the common variety.
The farmer who owns the trees has known of them for about eight years. He reports that they ripen fully ten days earlier than the others, and are much sweeter.

Dr. G F. Ledingham of the University reports that while a chokecherry with whitish to yellow fruits and described as "leucocarpa" is listed in Gray's manual of botany, the Yorkton find is the first received at the university. Neither he nor Dr. R. C. Russell, leading 